\title{
Physical-Anatomical and Initial Growth of Tabebuia roseoalba (Ridl.) under Different Water Regimes
}

Silvana de Paula Quintão Scalon ${ }^{1}$ (1) 0000-0003-2024-7695

Rosilda Mara Mussury ${ }^{1}$ (D) 0000-0002-8961-9146

\begin{abstract}
The present work evaluated the physical-anatomical and initial growth of Tabebuia roseoalba seedlings exposed to different water regimes. The seedlings were grown under 100, 50, 25 and 12.5\% of the water retention capacity (WRC). After 90 days, the following aspects were evaluated: height, diameter, fresh and dry weights of aerial and root, root length, and leaf area, Dickson quality index, liquid assimilation rate, relative growth rate, specific leaf area, stomatal index, and number of trichomes and leaf epidermal cells. The results indicated seedlings have greater initial growth and quality when cultivated at 100\% WRC, and 25 and $12.5 \%$ WRC represented stress conditions for the plants. The species is hypostomatous with anomocytic stomata. The number of stomata, the stomatal index, and the number of epidermal cells did diminish with reduced water availability. The number of trichomes were larger on the adaxial face as water availability decreased.
\end{abstract}

Keywords: anatomy, seedling production, water stress.

\section{Introduction and objectives}

One of the greatest difficulties to cultivate native species is the available water in the soil, and there are few studies demonstrating this availability in the soil and its transfer to the plants, which can affect the establishment of individuals (Chirino et al., 2017).

Under conditions of low soil water availability, some metabolic processes are affected, with the partial or total closing of the stomata to limit water loss and consequent reduction in $\mathrm{CO}_{2}$ acquisition, which can lead to negative growth affects - including reduction of leaf expansion. Moreover, it can also accelerate their senescence and abscission (which will directly affect photosynthesis), leaf abscission, inhibiting the internodes elongation and affecting root and shoot growth, the increased deposition of wax and increased trichome growth on the leaf surfaces (Jeromine et al., 2019; Scalon et al., 2011; Rosa et al., 2017; Silva et al., 2016).

According to a review by Abbade \& Takaki (2014) the "Ipê-branco", Tabebuia roseoalba (Ridl.) Sandwith, is a tree species widely used in urban forestry and recovery of degraded areas with great ornamental, medicinal and commercial value. The recommended mixture for seedling production (soil + sand + semi-decomposed chicken-bed wastes) promotes good seedling heights, radical-hypocotyl transition zone diameters, chlorophyll indices, leaf areas, root lengths, and dry weights of both the aerial and root portions (Macedo et al., 2011).

Seedling quality is an extremely important factor for successful reforestation, and they must be produced in sufficient quantity and quality to overcome adversities they will inevitably experience under field conditions and to have high survival percentages (Farias et al., 2007).

As there is very little information available about the ecophysiology and leaf anatomical of this species, the present work sought to evaluate the physical-anatomical and initial growth of Tabebuia roseoalba (ipê-branco) seedlings under different soil-water regimes.

\section{Materials and methods}

The seeds were sown into expanded polystyrene (Isopor) germination trays with 128 cells containing Bioplant commercial

${ }^{1}$ Universidade Federal da Grande Dourados (UFGD), Dourados, MS, Brasil 
germination substrate and subsequently maintained in an outdoor nursery covered with shade screen (50\%).

After germination and initial growth, approximately $15 \mathrm{~cm}$ tall seedlings were transplanted to plastic bags ( $3 \mathrm{~kg}$ capacity) containing soil + sand + semi-decomposed chicken-bed wastes (1:1:1) substrate and maintained under $50 \%$ shading for 10 more days. At the end of this period the plants were exposed to the following water regimes: 100, 50, 25 and 12.5\% water retention capacity (WRC), calculated based on the soil substrate density (Souza et al., 2000).

After 90 days of treatment, three seedlings from each treatment condition were evaluated in terms of stem height, radical-hypocotyl transition zone diameter, fresh and dry weights of the aerial and root portions (FWAP; FWRP; DWAP and DWRP respectively - g), average root length (ARL $-\mathrm{cm}$ ), and leaf area $\left(\mathrm{LA}-\mathrm{cm}^{2}\right)$ using a Li Cor 3000 leaf area meter.

The Dickson quality index was calculated using the Equation 1 (Dickson et al., 1960).

$$
\mathrm{DQI}=[\text { total dry material } /(\mathrm{RAD}+\mathrm{RAPR})]
$$

Where RAD: height/diameter ratio, RAPR: the ratio between the dry weight of the aerial portion/dry weight of the root.

We also analyzed the liquid assimilation rate (LAR $\mathrm{g} \mathrm{cm}^{-2}$ day $\left.^{-1}\right)$, relative growth rate $\left(R G R-\mathrm{g} \mathrm{g}^{-1}\right)$, and specific leaf area (LRA $-\mathrm{cm}^{2} \mathrm{~g}^{-1}$ ) expressed according to Equation 2,3 and 4 .

$$
\begin{aligned}
& R G R=\left(\ln P_{2}-\ln P_{1}\right) /\left(t_{2}-t_{1}\right) g \cdot g-1 \cdot d a y^{-1} \\
& \mathrm{LAR}=\mathrm{P}_{2}-\mathrm{P}_{1} / \mathrm{A}_{2}-\mathrm{A}_{1} \times \ln \mathrm{A}_{2}-\ln \mathrm{A}_{1} / \mathrm{t}_{2}-\mathrm{t}_{1} \text { g.dm }{ }^{2} \cdot \text { day }^{-1}
\end{aligned}
$$

$\mathrm{LRA}=\mathrm{A} / \mathrm{P}$

Where ln: Napierian logarithm; P: total mass of plant; $t_{2-} t_{1}$ interval between evaluations; A: leaf area of plant.

The experiment was conducted with three repetitions of 12 seedlings each. The results were analyzed for variance, and the averages compared using the Tukey's test at a 5\% level of probability.

Ten totally expanded leaves from different plants subjected to each of the treatments were used for anatomical studies. Free-hand paradermal cuts were made in the median region of the adaxial and abaxial portions of the leaf with a razor blade. Leaf surface impressions were made in the same areas with Super Bonder glue to analyze the shape and number of common epidermal cells, the characteristics of the stomata on the abaxial and adaxial leaf faces, and the quantity of trichomes. Three optical fields were examined in the median region of the leaf blade, for a total of 30 fields per treatment. Stomatal counts were made using a Colleman light microscope with a camera lucida attachment, following the methodology described by Labouriau et al. (1961).

The stomatal index (SI) was calculated with the Equation 5 (Wilkinson, 1979 as cited in Hu et al., 2015).

$\mathrm{SI}(\%)=\mathrm{SD} /(\mathrm{SD}+\mathrm{ED}) \times 100$

Where Sn: number of stomata; Em: number of epidermal cells.

The results were documented as drawings made with the aid of the camera lucida, with its appropriate scales.

\section{Results}

The evaluation of seedling growth of Tabebuia roseoalba after 90 days in each treatment regime indicated the plants achieved the greatest maximum height when exposed to conditions of high water availability, and were $50 \%$ smaller under restricted water conditions; height values did not vary significantly among the intermediate treatments. Stem diameters were greater at $100 \%$ WRC (Table 1).

The average root lengths of T. roseoalba were greater at $100 \%$ WRC and smaller at $12.5 \%$ WRC. The leaf area of T. roseoalba seedlings were likewise greater with higher water availability, and decreased under water-deficit conditions (Table 1).

The average values of the fresh and dry weights of the aerial portions and roots of $T$. roseoalba seedlings were lower under conditions of restricted water availability, with FWAP values being $73 \%$ and $92 \%$ lower under $25 \%$ and $12.5 \%$ WRC respectively, while FWRP, DWAP and DWRP values were $50 \%$ lower on the average (Table 1), indicating that the T. roseoalba aerial portion was more influenced by water deficit conditions than the root system.

The Dickson quality index (DQI) was higher in seedlings cultivated at $100 \%$ WRC, and lower with decreasing soilwater availability (although without significant differences between the 25 and $12.5 \%$ WRC conditions) (Table 2). This indicates that the best growing conditions were provided under the $100 \%$ WRC regime.

As the seedlings cultivated under $12.5 \% \mathrm{WRC}$ conditions did not demonstrate satisfactory growth or healthy aspects, 
they were not evaluated in terms of LRA, RGR, or LAR which were significantly higher in seedlings grown at $100 \%$ WRC (Table 2), with larger leaf areas and presumed greater production of photoassimilates.

Ostiole openings and stomatal indices were greater at $100 \%$ WRC. The closing of the stomata under water-stress conditions was observed at $12.5 \%$ WRA (Table 3 ).

The paradermal sections showed that T. roseoalba is a hypostomatous species with anomocytic stomata and star-shaped trichomes on both leaf surfaces (Table 3 and Figure 1).
Stomata were sporadically observed on the adaxial leaf face near the central vein (Figure $1 \mathrm{~g}$ ). The cell walls on the abaxial face (Figure 1a, b, c and d) were more sinuous than those on the adaxial face (Figure 1e, f, g and h), although no modifications were observed in these structures in response to the deficit water regimes.

The number of stomata, the stomatal index, and the quantity of epidermal cells did diminish with reduced water availability; however, the trichomes on the abaxial face did not vary with different water regimes, although a lot of these structures were observed on the adaxial face as water availability decreased.

Table 1. Height, diameter, average root length (ARL), leaf area, fresh weight of the aerial portion (FWAP), fresh weight of the root (FWRP), dry weight of the aerial portion (DWAP) and dry weight of the roots (DWRP) of Tabebuia roseoalba seedlings after 90 days of growth under different soil water conditions.

\begin{tabular}{|c|c|c|c|c|}
\hline $\begin{array}{l}\text { Water regimes } \\
\text { (\% WRC) }\end{array}$ & $\begin{array}{l}\text { Height } \\
(\mathrm{cm})\end{array}$ & $\begin{array}{l}\text { Diameter } \\
(\mathbf{m m})\end{array}$ & $\begin{array}{l}\text { ARL } \\
(\mathrm{cm})\end{array}$ & $\begin{array}{c}\text { Leaf area } \\
(\mathrm{cm})^{2}\end{array}$ \\
\hline 100 & $28.16 \mathrm{a}$ & $11.99 \mathrm{a}$ & $30.50 \mathrm{a}$ & $831.89 \mathrm{a}$ \\
\hline 50 & $25.49 \mathrm{ab}$ & $9.31 \mathrm{~b}$ & $24.66 \mathrm{ab}$ & $716.43 \mathrm{~b}$ \\
\hline 25 & $17.88 \mathrm{bc}$ & $8.54 \mathrm{~b}$ & $24.33 \mathrm{ab}$ & $296.59 \mathrm{c}$ \\
\hline \multirow[t]{2}{*}{12.5} & $12.05 \mathrm{c}$ & $8.52 \mathrm{~b}$ & $21.50 \mathrm{~b}$ & $80.89 \mathrm{~d}$ \\
\hline & FWAP(g) & FWRP(g) & DWAP(g) & $\operatorname{DWRP}(\mathrm{g})$ \\
\hline 100 & $17.96 \mathrm{a}$ & $23.02 \mathrm{a}$ & $6.60 \mathrm{a}$ & $8.72 \mathrm{a}$ \\
\hline 50 & $14.60 \mathrm{a}$ & $18.26 \mathrm{~b}$ & $5.93 \mathrm{~b}$ & $6.07 \mathrm{~b}$ \\
\hline 25 & $4.80 \mathrm{~b}$ & $14.25 \mathrm{c}$ & $4.01 \mathrm{c}$ & $4.68 \mathrm{c}$ \\
\hline 12.5 & $1.30 \mathrm{~b}$ & $12.44 \mathrm{~d}$ & $3.38 \mathrm{~d}$ & $3.05 \mathrm{~d}$ \\
\hline
\end{tabular}

Averages followed by the same lowercase letters in a column are statistically equivalent according to the Tukey's test at a $5 \%$ level of significance.

Table 2. Dickson quality index, liquid assimilation rate (LAR), relative growth rate (RGR), and specific leaf area (LRA) of Tabebuia roseoalba seedlings after 90 days of growth under different soil water conditions.

\begin{tabular}{cccccc}
$\begin{array}{c}\text { Water regimes } \\
(\% \text { WRC) }\end{array}$ & DQI & $\begin{array}{c}\text { LAR } \\
\left(\mathbf{g ~ c m}^{2} \mathbf{~ d}^{-1}\right)\end{array}$ & $\begin{array}{c}\text { RGR } \\
\left(\mathbf{g ~ g ~ g}^{-1} \mathbf{d}\right)\end{array}$ & $\begin{array}{c}\text { LRA } \\
\left(\mathbf{c m}^{2} \mathbf{g}^{-1}\right)\end{array}$ & $\begin{array}{c}\text { Opening ostiole } \\
(\mathbf{m m})\end{array}$ \\
\hline 100 & $4.94 \mathrm{a}$ & $0.2643 \mathrm{a}$ & $0.0168 \mathrm{a}$ & $72.41 \mathrm{a}$ & $31.5 \mathrm{a}$ \\
50 & $3.23 \mathrm{~b}$ & $0.0007 \mathrm{~b}$ & $0.0102 \mathrm{~b}$ & $58.41 \mathrm{~b}$ & $26.3 \mathrm{~b}$ \\
25 & $2.95 \mathrm{c}$ & $0.0002 \mathrm{c}$ & $0.0027 \mathrm{c}$ & $29.94 \mathrm{c}$ & $22.0 \mathrm{c}$ \\
12.5 & $2.90 \mathrm{c}$ & - & - & - & -
\end{tabular}

Averages followed by the same lowercase letters in a column are statistically equivalent according to the Tukey's test at a $5 \%$ level of significance.

Table 3. Numbers of stomata, trichomes, epidermal cells, stomatal indices, and ostiole openings on the leaves of Tabebuia roseoalba seedlings after 90 days of exposure to different soil water regimes.

\begin{tabular}{ccccc}
$\begin{array}{c}\text { Face leaf } / \\
\text { WRC }\end{array}$ & Stomata & Trichomes & Epidermal cells & Stomatal indices \\
\hline & & Abaxial & & $78.19 \mathrm{c}$ \\
\hline $12.5 \%$ & $14.2 \mathrm{c}$ & $15.8 \mathrm{a}$ & $3.71 \mathrm{~b}$ & $83.75 \mathrm{c}$ \\
\hline $50 \%$ & $24.9 \mathrm{c}$ & $15.53 \mathrm{a}$ & $4.96 \mathrm{~b}$ & $92.44 \mathrm{~b}$ \\
\hline
\end{tabular}


Table 2. Continued...

\begin{tabular}{ccccc}
$\begin{array}{c}\text { Face leaf } / \\
\text { WRC }\end{array}$ & Stomata & Trichomes & Epidermal cells & Stomatal indices \\
\hline $100 \%$ & $48.2 \mathrm{a}$ & $16.46 \mathrm{a}$ & $10.81 \mathrm{a}$ & $81.69 \mathrm{a}$ \\
\hline $12.5 \%$ & 0.0 & Adaxial & $9.23 \mathrm{a}$ & 0.0 \\
$25 \%$ & 0.0 & $18.81 \mathrm{a}$ & $3.91 \mathrm{~b}$ & 0.0 \\
$50 \%$ & 0.0 & $13.66 \mathrm{~b}$ & $1.51 \mathrm{c}$ & 0.0 \\
$100 \%$ & 0.0 & $13.61 \mathrm{~b}$ & $1.46 \mathrm{c}$ & 0.0
\end{tabular}

Averages followed by the same lowercase letters in a column are statistically equivalent according to the Tukey's test at a $5 \%$ level of significance.
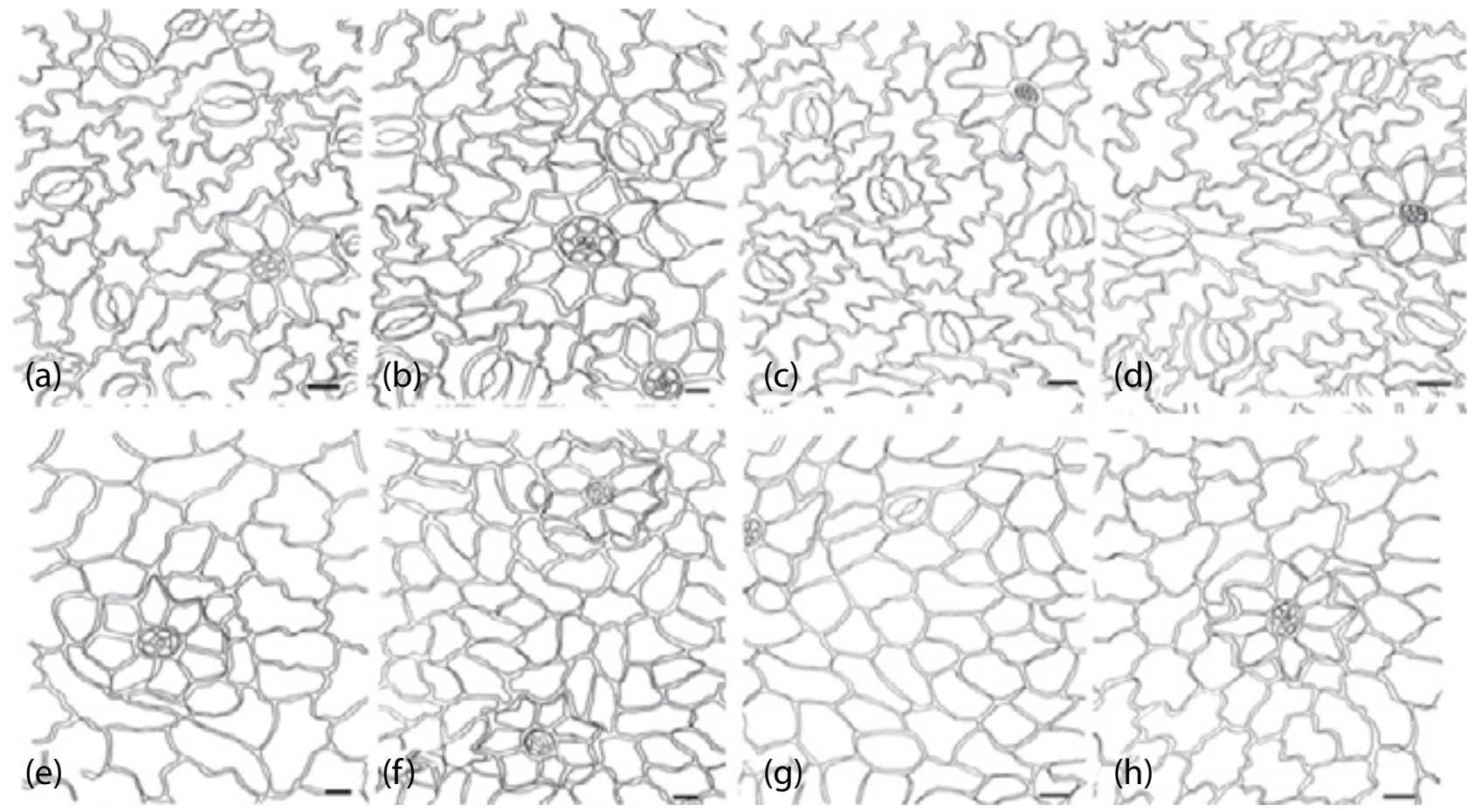

Figure 1. Paradermal sections of Tabebuia roseoalba leaves exposed to different water retention capacity.

Abaxial face: (a) 100\% WRC, (b) 50\% WRC, (c) 25\% WRC and (d) 12.5\% WRC. Adaxial face: (e) 100\% WRC, (f) 50\% WRC, (g) 25\% WRC and (h) 12.5\% WRC. Bar: 50 $\mu \mathrm{m}$.

\section{Discussion}

Based on the results of this study, we concluded that all aspects of plant growth and development are affected by soil water deficiencies and the precise effects of these deficits on plant development will depend on the intensity and duration of the stress, on the growth stage of the plant and genetic responses - resulting in diverse morpho-physiological modifications or even plant death (Martins et al., 2010).

It is observed in the literature that, for overcoming the water deficit stress, plants invest in root biomass with reduction of leaf expansion and, consequently, reduced consumption of carbon, being observed reductions in the growth of shoots
(Carvalho et al., 2012.), leaf area (Jeromine et al., 2019; Mar et al., 2013; Scalon et al., 2011) and increased ratio of root biomass and shoot (Silva et al., 2016; Verma et al., 2012). However, this behavior was not observed in T. roseoalba seedlings, probably due to the assessed stage of development or the period in which they remained in culture conditions

Plant responses to soil water conditions are quite variable, but tree species tend to attain greater heights and diameter as soil-water becomes more available. Seedlings of Tabebuia aurea (Silva Manso) Benth. \& Hook. f. ex S. Moore, Alibertia edulis (Rich) A. Rich. ex DC., Guazuma ulmifolia Lam., Hymeneae coubaril $\mathrm{L}$. demonstrated greater heights when cultivated under conditions of greater water availability 
(Cabral et al., 2004; Jeromine et al., 2019; Scalon et al., 2011; Silva et al., 2016, respectively).

Qualea grandiflora Mart. seedlings native from the Cerrado (Brazilian savanna) did not show significant differences in terms of stem diameter when grown at different water retention capacity (12.5; 50 and $100 \%)$, showing linear growth during 120 days of exposure to all treatments (Vieira \& Gomes, 2011). These results indicate that the duration of exposure to deficit water conditions must be considered in growth evaluations. Increases in stem diameter depend on cambium layer activities, which are stimulated, in turn, by photosynthetic production and by hormones translocated from apical sites (Aguiar et al., 2011).

Jeromine et al. (2019) and Rosa et al. (2017) suggest that the balance between assimilate production and demand can be severely affected under water-deficit conditions due to reductions in photosynthetically productive leaf areas. The growth of the root system into the deepest soil levels allows plants to take advantage of the increased humidity and soil fertility at lower depths (depending on the morphological and genetic characteristics of the plant). Water-deficit conditions will diminish mitotic activity in plant cells and initiate the synthesis of abscisic acid in the roots, which is transported to different parts of the plant and can provoke (among other responses) precocious reproduction and leaf abscission (this helps to explain significant reductions of leaf area seen in the water-stressed T. roseoalba seedlings).

Similarly, G. ulmifolia seedlings did not have significant differences between the lengths of the largest roots after 35 days of cultivation under the same conditions as the present research, although the seedlings demonstrated higher root dry weights at 100 and $50 \%$ WRC; seedlings grown at $12.5 \%$ WRC died before the 83rd day of the experiment (Scalon et al., 2011).

Similar results were observed with $T$. aurea seedlings, which did not show any differences in relation to the ratio of the dry matter of the roots/dry mass aerial portions (DMRP/DMAP) after two days of treatment. However, starting at 90 days, the $25 \%$ WRC treatment seedlings were significantly smaller than the others (Cabral et al., 2004) indicating, once again, the importance of exposure time.

These results indicate that water deficits can severely affect growth and fresh and dry biomass accumulation in plants (Silva et al., 2016). Jeromine et al. (2019) observed that seedlings with greater root dry weights probably have greater chances of surviving water-stress during the dry season in the natural environment, and this characteristic is therefore extremely important for the successful growth of seedlings.

Another result that supported the above-mentioned analysis was the observation that the greatest water availability (100\% WRC) yielded the greatest increase in plant biomass; severe water deficiencies (12.5\% WRC) resulted in reduced growth, indicating T. roseoalba seedlings could not tolerate water deficit conditions for 90-day periods.

In the review by Gordin et al. (2016), we observed that leaf area is an important factor in plant photosynthetic production and will determine plant water-use, considering productivity will be severely inhibited under deficit water conditions. As such, under water-stress conditions, when there is a decrease in cell turgidity, there will be reductions in leaf expansion and size.

There are many references in the literature reporting the leaf area tends to be lower under conditions of lower water availability, including Cabral et al. (2004) for T. aurea, Scalon et al. (2011) for G. ulmifolia, Vieira \& Gomes (2011) for Q. grandiflora, Silva et al. (2016) for Hymeneae coubaril, Gordin et al. (2016) for Hancornia speciosa, and Jeromine et al. (2019) for A. edulis seedlings.

Dickson quality index is an appropriate parameter to measure the quality of seedlings, because it defines the strength and balance of biomass distribution in the change (Freitas et al., 2018; Gordin et al., 2016; Jeromine et al., 2019) the higher the value, the better the quality changes (César et al., 2014)

Ostiole openings and stomatal indices were greater at $100 \%$ WRC, indicating that the plants could better absorb atmospheric $\mathrm{CO}_{2}$ and would have higher photosynthetic rates under these conditions. The closing of the stomata under water-stress compromises $\mathrm{CO}_{2}$ acquisition and reduces biomass production and plant productivity - yielding smaller plants with reduced dry weight accumulations, as reported by Rosa et al. (2017) for Copaifera langsdorffii Desf., as well as in the study presented here.

Other factors such as changes in plant hormonal balances or reductions in soil nutrient uptake, translocation, respiration or protein metabolism will also reduce plant growth and help to explain the reductions in the dry weight of the aerial and root portions of plants and diminished root lengths as water-stress became more severe, according to the results found for C. lansdorffii (Rosa et al., 2017), Hymeneae coubaril L. (Freitas et al., 2018) and A. edulis (Jeromine et al., 2019).

The water deficit caused stomatal changes (density, index, opening, size, diameters) related to the regulation of gas exchange under stress conditions. Therefore, leaves with fewer stomatal openings show higher efficiency under water-deficit conditions, because they have smaller stomatal pores, which reduces water loss through transpiration (Rosa et al., 2017). This tendency was observed in young plants exposed to $25 \%$ WRC in relation to $50 \%$ WRC in the present work. Decreases in the number of stomata were also observed in young T. aurea - plants experiencing water deficits (25\% WRC) showed decreases in the number of 
stomata after 90 to 120 days as compared to $100 \%$ WRC treatments (Cabral et al., 2004).

Plants can change their phenotype in response to abiotic stress, a phenomenon known as phenotypic plasticity. This plasticity can result in anatomical changes of the leaves to mitigate the effects of abiotic extremes. Silva et al. (2005) observed in their review that responses involve changes in leaf area, leaf orientation and position foliage, trichomes and waxy cuticles, which affects even the growth of plants under low soil-water conditions.

\section{Conclusions}

Tabebuia roseoalba seedlings had greater initial growth and quality when cultivated at $100 \%$ water retention capacity, while seedlings grown under 25 and 12.5\% WRC demonstrated stress characteristics.

The species is hypostomatous with anomocytic stomata. The numbers of stomata, the stomatal index, and the numbers of epidermal cells did diminish with reduced water availability. The trichomes on the abaxial face did not vary among the different water regimes, although many of these structures were observed on the adaxial face as water availability decreased.

\section{Acknowledgements}

Conselho Nacional de Desenvolvimento Científico e Tecnológico (CNPq) and Fundação de Apoio ao Desenvolvimento do Ensino, Ciência e Tecnologia do Estado de Mato Grosso do Sul (Fundect).

\section{Submission status}

Received: 2 May 2017

Accepted: 7 July 2019

Associate editor: José Henrique Tertulino Rocha

\section{Correspondence to \\ Silvana de Paula Quintão Scalon}

Rod. Dourados Itahum, km 12, CEP 79825-070, Dourados, MS, Brasil e-mail: silvanascalon@ufgd.edu.br

\section{References}

Abbade LC, Takaki M. Biochemical and physiological changes of Tabebuia roseoalba (Ridl.) Sandwith (Bignoniaceae) seeds under storage. Journal of Seed Science 2014; 36(1): 100-107. 10.1590/ S2317-15372014000100013

Aguiar FFA, Kanashiro S, Tavares AR, Nascimento TDR, Rocco FM. Crescimento de mudas de pau-brasil (Caesalpinia echinata Lam.), submetidas a cinco níveis de sombreamento. Revista Ceres 2011; 58(6): 729-734. 10.1590/S0034-737X2011000600008
Cabral EL, Barbosa DCA, Simabukura EA. Crescimento de plantas jovens de Tabebuia aurea (Manso) Benth. \& Hook. f. ex S. Moore submetidas a estresse hídrico. Acta Botânica Brasílica 2004; 18(2): 241-251. 10.1590/S0102-33062004000200004

Carvalho JSB, Martins JDL, Moreira KA. Respostas fisiológicas de Hyptis pectinata (L.) Poit. ao estresse hídrico. Bioterra 2012; 12(2): 20-28. 51833118b91bb

César FRCF, Matsumoto SN, Viana AES, Bonfim JÁ. Crescimento inicial e qualidade de mudas de Pterogyne nitens Tull. conduzidas sob diferentes níveis de restrição luminosa artificial. Ciência Florestal 2014; 24(2): 357-366. 10.5902/1980509814573

Chirino E, Ruiz-Yanetti S, Vilagrosa A, Mera X, Espinoza M, Lozano P. Morpho-functional traits and plant response to drought conditions in seedlings of six native species of Ecuadorian Ecosystems. Flora 2017; 233: 58-67. 10.1016/j.flora.2017.05.012

Dickson A, Leaf AL, Hosner JF. Quality appraisal of white spruce and white pine seedlings stock in nurseries. Forest Chronicle 1960; 36: 10-13. 10.5558/tfc36010-1

Farias JA Jr, Cunha MCL, Farias SGG, Menezes JC Jr. Crescimento inicial de mudas de turco sob diferentes tipos de recipientes e níveis de luminosidade. Revista Brasileira de Ciências Agrárias 2007; 2(3): 228-232.

Freitas VMB, Scalon SPQ, Dresch DM, Bastos SS, Souza APR. Influence of exogenous application of abscisic acid on gas exchanges in Hymenaea courbaril L. (Fabaceae) seedlings subjected to water deficit. Floresta 2018; 48(2): 163-172. 10.5380/ rf.v48 i2.53076

Gordin CRB, Marques RF, Scalon SPQ. Emergence and initial growth of Hancornia speciosa (Gomes) seedlings with different substrates and water availability. Revista Ciências Agrárias 2016; 59(4): 352-361. 10.4322/rca.2353

Hu JJ, Xing YW, Turkington R, Jacques FMB, Su T, Huang YJ et al. A new positive relationship between $\mathrm{CO}_{2}$ and stomatal frequency in Quercus guyavifolia (Fagaceae): a potential proxy for palaeo-CO2 levels. Annals of Botany 2015; 115(5): 777-788. 10.1093/aob/mcv007

Jeromine TS, Mota LHS, Scalon SPQ, Dresch D, Scalon L. Effects of substrate and water availability on the initial growth of Alibertia edulis Rich. Floresta 2019; 49(1): 89-98. 10.5380/rf.v49i1.57122

Labouriau LG, Oliveira JG, Salgado-Labouriau UML. Transpiração de Schizolobium parahyba (Vell) Toledo I.: comportamento na estação chuvosa, nas condições de Caeté, Minas Gerais. Anais da Academia Brasileira de Ciência 1961; 33: 237-257.

Macedo MC, Rosa YBCJ, Rosa EJ Jr, Scalon SPQ, Tatara B. Produção de mudas de ipê branco em diferentes substratos. Cerne 2011; 17(1): 95-102. 10.1590/S0104-77602011000100011

Mar CC, Conceição HEO, Santos ABR, Viégas IJM, Silva FSN. Produção de massa seca e área foliar do açaizeiro sob déficit hídrico. Revista Agroecossistemas 2013; 5(2): 14-23. 10.18542/ragros.v5i2.1794

Martins MO, Nogueira RJMC, Azevedo Neto AD, Santos MG. Crescimento de plantas jovens de Nim-Indiano (Azadirachta indica a. juss. - Meliaceae) sob diferentes regimes hídricos. Revista Árvore 2010; 34(5): 771-779. 10.1590/S0100-67622010000500002

Rosa DB, Scalon SPQ, Cremon T, Ceccon F, Dresch DM. Gas exchange and antioxidant activity in seedlings of Copaifera langsdorffii Desf. 
under different water conditions. Anais da Academia Brasileira de Ciências 2017; 89(4): 3039-3050. 10.1590/0001-3765201720170499

Scalon SPQ, Mussury RM, Euzébio VLM, Kodama FM, Kissmann C. Estresse hídrico no metabolismo e crescimento inicial de mudas de mutambo (Guazuma ulmifolia Lam.). Ciência Florestal 2011; 21(4): 657-664. 10.5902/198050984510

Silva CA, Dourado Neto D, Silva CJ, Freitas CA. Development of Hymenaea courbaril seedlings in function of containers and irrigation blades. Revista Árvore 2016; 40(3): 487-498. 10.1590/010067622016000300012

Silva LM, Alquini Y, Cavallet VJ. Inter-relações entre a anatomia vegetal e a produção vegetal. Acta Botanica Brasilica 2005; 19(1): 183-194. 10.1590/S0102-33062005000100018
Souza CC, Oliveira FA, Silva IF, Amorim Neto MS. Avaliação de métodos de determinação de água disponível e manejo da irrigação em terra roxa sob cultivo de algodoeiro herbáceo. Revista Brasileira de Engenharia Agrícola e Ambiental 2000; 4(3): 338-342. 10.1590/ S1415-43662000000300006

Verma KK, Vatsa S, Gupta RK, Ranjan S, Verma CLM. Influence of water application on photosynthesis, growth and biomass characteristics in Jatropha curcas. Current Botany 2012; 3(4): 26-30.

Vieira EA, Gomes AS. Desenvolvimento inicial de plantas de pau-terra-do-cerrado sob diferentes regimes hídricos. Evolution, Biodiversity and Conservation 2011; 2(1): 58-65. 10.7902/ecb. v2i1.27 